Agnieszka Haska

\title{
Na marginesie serialu Sprawiedliwi, czyli (prawie) cała Polska ratuje Żydów
}

W kwietniu i maju 2010 roku Telewizja Polska wyemitowała siedmioodcinkowy serial Sprawiedliwi według scenariusza Wojciecha Tomczyka i w reżyserii Waldemara Krzystka. W opisach dla prasy TVP reklamowała serial jako „opowieść o Polakach ratujących Żydów w czasie wojny, ale także o miłości, przyjaźni, o zasadach, których nigdy się nie łamie, nawet w sytuacji, gdy stawką jest życie”" Scenarzysta i reżyser w wywiadach nie wypierali się również dydaktycznego wymiaru tej opowieści, która miała przywrócić „sprawie właściwe proporcje”2 i wreszcie pokazać prawdę o Polakach, którzy w „naturalnym odruchu”3 ratowali Żydów. Według recenzentów dydaktyka zdecydowanie wygrała tu ze sztuką: Adam Leszczyński z "Gazety Wyborczej” nazwał Sprawiedliwych „czytanką o Żegocie” przypominającą „patriotyczny komiks”, którego bohaterowie „są tak piękni i szlachetni, że aż nieciekawi” („Bardziej skomplikowane postaci każdy może sobie wyciąć z kartonu nożyczkami”) ${ }^{4}$. Czego zatem dowiedział się widz oglądający Sprawiedliwych?

Akcja serialu rozgrywa się w dwóch planach czasowych - krótko przed i w czasie II wojny oraz współcześnie, w marcu 2009 r. Część historyczna zaczyna się w 1938 r. na ulicy Bednarskiej w Warszawie, gdzie młody inżynier Stefan Kowalski (w tej roli Wojciech Solarz), śpieszący się na spotkanie w Ministerstwie Komunikacji w sprawie budowy metra, wpada na śliczną blondynkę imieniem Basia (Marta Chodorowska). W pierwszym odcinku poznajemy również innych bohaterów rodziców Stefana, państwa Kowalskich (Katarzyna Gniewkowska i Cezary Morawski), jego przyjaciół: bankiera Henryka i muzyka Zygmunta (Michał Żurawski, Jakub Mazurek), szefa - profesora Kaniewskiego (Jan Englert) oraz piosenkarkę Inę Palomę (Anna Dereszowska) i państwa Kaliskich - właścicieli kamienicy, gdzie mieszkają Kowalscy. Przedwojenna Warszawa to kwitnące miasto, gdzie pierwsza stacja metra ma zostać otwarta w sierpniu 1944 roku, a jedyny element niepokoju wprowadza do akcji serialu postać niemieckiego inżyniera, Hermanna Ulbrichta

\footnotetext{
${ }^{1}$ www.filmywjedynce.tvp.pl.

${ }^{2}$ Wywiad z reżyserem serialu, Waldemarem Krzystkiem, przeprowadzony przez Piotra Zychowicza, Wyciąnnęli rękę do Żydów, „Rzeczpospolita”, 15 III 2010.

${ }^{3} \mathrm{http}: / /$ www.polskieradio.pl/trojka/TrojkaPoTrzeciej/artykul160879.html.

${ }^{4}$ Czytanka o Żegocie, „Gazeta Telewizyjna”, dodatek do „Gazety Wyborczej” z 9 IV 2010.
} 
(Borys Szyc), który podczas rautu w restauracji po pijanemu pyta Stefana, czy bankier Henryk i jego żona to Żydzi. Sielanka jednak szybko się kończy z wiadomych powodów; w czasie kampanii wrześniowej Stefan spotyka znów Basię, tym razem $\mathrm{w}$ roli sanitariuszki. Tu scenariuszowe prefiguracje dotyczące Zagłady tracą wszelką subtelność, szpitalik polowy mieści się bowiem w Treblince, a gdy po kapitulacji Warszawy cywilny garnitur szyje Stefanowi miejscowy Żyd, rozmowę o tym, że „Niemcy u siebie straszne rzeczy z Żydami wyprawiają”, podsumowuje pytaniem: „ale co złego może spotkać Żyda w takiej cichej i spokojnej wsi jak Treblinka?”.

W odcinku drugim akcja przenosi się do 1941 r. Stefan, już jako mąż Basi, początkowo nie chce się angażować w konspirację czy inne niebezpieczne zajęcia - ale jest godnym zaufania prawdziwym Polakiem-patriotą, który wraz z rodziną wieczorami czyta na głos Pana Tadeusza. W odróżnieniu od głównego bohatera, prawie wszyscy jego znajomi wykazują się lepszym zmysłem obserwacji i już w 1941 r. wiedzą, jaki los grozi Żydom - bez wahania angażują się więc w ich ukrywanie oraz pomoc. Twórcy serialu nie skupili się jednak na jednej historii ukrywających i ukrywanych i wzięli stosowny rozmach, chcąc pokazać tu zarówno pomoc instytucjonalną, jak i indywidualną. Basia, zainspirowana przez przyjaciółkę Irenę (nazwisko nie pada, ale łatwo się go domyślić) słowami: „Prawdziwych przyjaciół poznaje się w biedzie, a oni są w biedzie! Liczy się każde uratowane życie!”, wstępuje do bliżej nieokreślonej konspiracji (w odcinku czwartym zidentyfikowanej jako Żegota) i zajmuje się ratowaniem podawanych przez dziurę $\mathrm{w}$ murze getta dzieci i oddawaniem ich do klasztoru. Profesorostwo Kaniewscy, mieszkający w Tarczynie w małym dworku, w szopie stojącej w ogrodzie ukrywają znajomych: mecenasa Kohna z rodziną. Piątek, dozorca kamienicy, gdzie mieszkają Kowalscy, ukrywa jej właścicieli - rodzinę Kaliskich. Z kolei do mieszkania muzyka Zygmunta puka uciekinierka z getta, Ina Paloma, błagając: „nie wyganiaj mnie”, a ten, oczywiście, natychmiast przyjmuje ją pod swój dach. Jak się okazuje w trzecim odcinku, nawet kolejarz z Treblinki pomaga w ukrywaniu wspomnianego żydowskiego krawca. Ukrywanie jest tu rzeczywiście „naturalnym odruchem” sąsiada, który pomaga sąsiadowi. Gdyby jednak widz miał jakieś wątpliwości co do tej dobrosąsiedzkiej przyjaźni, w drugim odcinku profesor Kaniewski wyjaśnia, dlaczego pomaga Żydom: „Całe życie byliśmy sąsiadami. Od pokoleń moja rodzina mieszkała w ich kamienicy. Teraz oni pomieszkają u nas”. Aby dopełnić ten obraz wszystkich warstw społecznych ukrywających Żydów, w odcinku czwartym Basia przewozi chłopca i dziewczynkę z klasztoru do chłopskiej rodziny pod Pilawą, gdzie już ukrywa się dziewiątka dzieci.

To ukrywanie się pokazane jest w serialu w sposób, który oględnie można określić jako dość nielogiczny. Z jednej strony cały czas podkreśla się zagrożenie, przy czym bardziej kładzie się nacisk na karę śmierci dla Polaków (bo co stanie się z Żydami, przecież wiadomo). Dużo miejsca poświęca się również kwestiom logistycznym, szczególnie w wątku Iny Palomy, która jest zbyt sławna i ma zły wygląd; w domu Zygmunta zjawia się fryzjer, który farbuje ją na blond, a Basia załatwia jej metrykę chrztu i kenkartę oraz przekazuje jej modlitewno-kulturowe know-how. Nawiasem mówiąc, zdaje się, że głównym problemem dziewczyny w konspiracyj- 
nej pracy jest okłamywanie męża, że wychodzi spotkać się z pacjentem/koleżanką/kimś innym (niepotrzebne skreślić). Co ciekawe, wątek płacenia za ukrywanie pojawia się tutaj wprost tylko raz - Basia przekazuje pieniądze „od komitetu” oraz „od rodziców” chłopu pod Pilawą. O pieniądzach wspomina również profesor Kaniewski; pani Kohn bowiem choruje, w związku z czym jej mąż wydał majątek na morfinę. Nie ma jednak mowy o zarabianiu na ukrywaniu Żydów, a ukrywający dzielą się z nimi wszystkim, co mają. Na wszelki wypadek wyraźnie zostaje podkreślone, że „okradanie człowieka w potrzebie to wielki grzech”.

Z drugiej jednak strony w pewnych momentach, jak za dotknięciem czarodziejskiej różdżki, zagrożenie znika. Ina dzięki papierom i blond włosom przestaje być rozpoznawalna do tego stopnia, że może pozwolić sobie na spacer parkową alejką, podczas którego nuci swój największy przebój Kogo nasza miłość obchodzi. Nikt również nie zwraca jej uwagi, że śpiewanie tej piosenki na dwa głosy z fryzjerem może spalić kryjówkę i zaalarmować sąsiadów, nie mówiąc już o tym, że włosy mogła ufarbować sama, bez angażowania w to dodatkowej osoby. Z kolei w szóstym odcinku konspiracyjny zwierzchnik Basi zabiera dwójkę chłopców z klasztoru do knajpy, aby tam zidentyfikowali kolaboranta Pilnika, który pomaga Niemcom w poszukiwaniu kryjówek żydowskich dzieci. Pytana o zgodę siostra przełożona z klasztoru nie ma z tym żadnego problemu, oprócz tego, że „bierze na siebie ciężki grzech”, wiedząc, że pozytywna identyfikacja oznacza śmierć zdrajcy. To jednak mało istotne szczegóły w porównaniu z tym, że główny bohater, choć o niczym nie wie i nie chce wiedzieć, błyskawicznie dowiaduje się, kto gdzie się ukrywa i kto komu pomaga. Oto podczas wesela jego i Basi, które odbywa w majątku profesorostwa Kaniewskich, Stefan w nocy widzi panią domu niosącą wodę do szopy - aby nie było wątpliwości, że chodzi o Żydów, profesorowa woła na wszelki wypadek: „Moryc, wychodźcie!”. Przy tej okazji bohater (oraz widz) dowiaduje się w sposób jasny i klarowny, co oznacza pomoc Żydom. Kaniewski prosi Stefana, aby poczęstował Kohnów papierosami, po czym informuje go, że właśnie dopuścił się czynu - według Niemców - zbrodniczego i może być za to ukarany śmiercią. Na marginesie, ten wątek papierosowy nie doczekał się w serialu rozwinięcia; przy obecnych trendach antynikotynowych mógłby doprowadzić widza do interesujących, acz niechcianych konkluzji. Wracając do Stefana - wkrótce po weselu jego matka opowiada mu przy kolacji koleje losu rodziny Kaliskich, którzy zostali zawróceni przez Szwajcarów na granicy i musieli wrócić do Warszawy; pani Kowalska zna tę historię, gdyż spotkała panią Kaliską, która „czasem wychodzi...”. Z kolei o Inie mówi przyjacielowi ukrywający ją Zygmunt. Bardziej tajemniczy jest kolejarz z Treblinki, który udaje, że nie zna żadnego żydowskiego krawca, ale w końcu bierze pieniądze dla niego i wspomina, że przydałyby się lekarstwa. Wreszcie, Stefan widzi na ulicy Basię pod rękę z tajemniczym mężczyzną i podejrzewa ją o romans. Podczas konfrontacji żona wyjaśnia, że działa w Żegocie a żeby mąż nie awanturował się zbytnio o pracę w konspiracji, dodaje zaraz, że jest w ciąży, więc o dalszym działaniu w podziemiu nie może już być mowy.

Oczywiście, wszystko to służy powolnemu przeciąganiu Stefana na dobrą, pomagająco-konspiracyjną stronę mocy. Główny bohater w końcu „dorabia się” swo- 
ich własnych, przez siebie ukrywanych Żydów. Oto chowając broń w dawnych tunelach metra, spotyka tam grupę uciekinierów z getta, $w$ tym przyjaciela-bankiera Henryka i jego żonę, którym przynosi jedzenie. Ten wątek jednak szybko się urywa, a Stefan włącza się w ratowanie żydowskich dzieci oraz wstępuje do konspiracji, by zlikwidować kolaboranta Pilnika. Nawiasem mówiąc, w scenie wykonania wyroku scenarzysta serialu zaproponował dość oryginalne podejście do zagadnienia - po zastrzeleniu zdrajcy na podwórku kamienicy egzekutorzy bynajmniej nie uciekają z miejsca zdarzenia, ale wymieniają gniewne spojrzenia i zadają sobie pytania retoryczne: „Łatwe to jest? Łatwe?!”. Wreszcie Stefan i ciężarna Basia przenoszą się do Tarczyna, aby zająć się rodziną Kohnów; profesorowa dostała ataku apopleksji przy obieraniu ziemniaków i Kaniewski musi być w szpitalu przy żonie. Do dworku wpadają Niemcy, którzy zabijają Żydów oraz Stefana, bohatersko rzucającego się na jednego z żołnierzy; podczas strzelaniny udaje się uciec Basi oraz najmłodszemu z Kohnów, Jakubowi, który ukrył się na dachu. Tu znów mamy do czynienia z zastanawiającą nielogicznością: kiedy podczas ucieczki Basia zaczyna rodzić, Jakub biegnie po pomoc i spokojnie, bez żadnych przeszkód, wraca z lekarzem.

Te wszystkie nielogiczności można jednak wyjaśnić w prosty sposób, jeśli przyjmie się założenie twórców serialu: nawet ci Polacy, którzy nie ratują Żydów, nie stanowią dla nich zagrożenia. Scenarzysta Wojciech Tomczyk, wypowiadając się dla Programu Trzeciego Polskiego Radia, rozszerzył nawet tę myśl: według niego „większość Polaków była obojętna wobec sprawy żydowskiej, ale była to bardziej obojętność życzliwa niż taka, jaka jest pokazana w zakłamanym filmie Lista Schind-

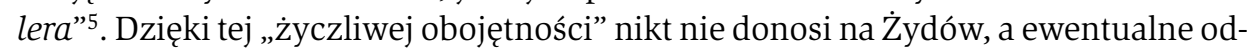
krycie żydowskich kryjówek Niemcy zapewne zawdzięczają wyłącznie prekognicji wykształconej dzięki gorączce poszukiwaczy złota. W Sprawiedliwych mamy do czynienia z dwoma takimi przypadkami. Oprócz opisanego powyżej wtargnięcia Niemców do dworku Kaniewskich, gdzie powodem miała być krążąca w okolicy plotka o zakopaniu żydowskich skarbów w jakimś ogrodzie, gestapo zjawia się również u dozorcy Piątka, bez problemu odnajdując zakamuflowaną za ścianą kryjówkę i krzycząc: „Gdzie jest złoto?”.

Oprócz programowo złych Niemców, w serialu pojawiają się inne niezupełnie kryształowe postacie. Należy do nich matka Zygmunta, pani Lipińska, niechętna Inie. Mimo przyjęcia jej pod swój dach („gość w dom, Bóg w dom”) wciąż wygłasza zdania o tym, jak w getcie Żydzi są szczęśliwi, bo wreszcie są u siebie i że Ina również powinna wrócić „do swoich”. Jak jednak się zdaje, od tego, że Ina jest Żydówką, bardziej przeszkadza jej rodząca się miłość między śpiewaczką-mężatką a jej synem: kiedy dowiaduje się, że Ina kocha Zygmunta, żąda, aby opuściła jej dom. Pani Lipińska nie posuwa się jednak do donosu; to już działka wspominanego powyżej kolaboranta, Joachima Pilnika, Ślązaka z Nowego Bytomia - co może być interpretowane jako fakt, że zdrajca jest niezupełnie Polakiem. Pilnik jest jedyną w serialu postacią, która zarabia na Żydach - za pieniądze wyprowadza ludzi z getta i oddaje w ręce

${ }^{5}$ http://www.polskieradio.pl/trojka/TrojkaPoTrzeciej/artykul160879.html. 
gestapo; za tę działalność czeka go smutny koniec. Notabene w serialu opowiadającym o ukrywanych Żydach nie ma ani jednej postaci szmalcownika. Szmalcownicy są wspominani jedynie anegdotycznie - fryzjer Franciszek opowiada, że zrobili się tak bezczelni, iż nawet Polaków łapią. Wreszcie, najciekawszą postacią z tego kręgu osób jest ojciec Stefana, który przypadkowo trafia na wizytę gestapo u Piątka, kiedy przychodzi prosić dozorcę o naprawienie kolanka od umywalki. Niemcy stawiają go pod ścianą kamienicy wraz z Żydami i rodziną dozorcy; kiedy pan Kowalski widzi wycelowany w nich karabin, zaczyna krzyczeć, że jest Niemcem. Kaliscy i Piątkowie giną, zaś Kowalski przeżywa załamanie psychiczne i trafia do szpitala psychiatrycznego w Tworkach, gdzie popełnia samobójstwo; przed śmiercią wyznaje Basi, że gestapo kazało mu udowodnić, że jest Niemcem i zabić pozostałych. Przesłanie zatem jest proste: zaprzaństwo kończy się psychiczną chorobą i samobójstwem, a zdrada śmiercią z rak podziemia. Lipińska też zostaje poniekąd ukarana: zrozpaczony powrotem Iny do getta Zygmunt postanawia zemścić się na Niemcach i wpada z bronią do klubu „Tivoli”, gdzie ginie w trakcie strzelaniny.

Ale prawdziwe armaty propagandowej dydaktyki wytoczono w scenach serialu dziejących się współcześnie. Każdy odcinek kończy się przeskokiem do roku 2009. W pierwszym prawie dziewięćdziesięcioletnia Barbara (Zofia Tomaszewska-Charewicz) ma być odznaczona medalem „Sprawiedliwy wśród Narodów Świata” za uratowanie Jakuba Kohna (Wojciech Pszoniak), światowej sławy skrzypka. Z medalem wiąże się wyjazd do Izraela. Od odwiedzającej Barbarę pani konsul dowiadujemy się bowiem, że nie tylko „nam w Izraelu zależy na tym, żeby Sprawiedliwi przyjeżdżali do nas”, ale „jest to także w waszym interesie”. Syn Barbary, Marcin (Krzysztof Stroiński) niechętnie odnosi się do tego pomysłu, zadając dużo retorycznych pytań, m.in.: „A tacie co przywróci życie, medal czy drzewko?”, oraz: „nie mogliby po prostu zostawić nas w spokoju?”. Bardziej entuzjastycznie do sprawy podchodzi wnuczka Bogna (Małgorzata Buczkowska), która decyduje się pojechać z babcią do Izraela. Przy okazji chce wyedukować swojego chłopaka, lekarza Jana, który ma poważne luki w wykształceniu, bo pyta, czy tych Żydów to komuniści zabijali; jego ojciec z kolei podnosi kwestie w rodzaju: „Po co nam ten medal, przecież wciąż słyszę o polskim antysemityzmie”. Prawdziwy cel propagandowo-edukacyjny ujawnia się jednak w odcinku czwartym, kiedy na lotnisku Bogna rozmawia z przypadkowo spotkanym Amerykaninem i mówi mu, że leci do Izraela z babcią odebrać medal za ratowanie Żydów, na co jej rozmówca zdziwiony pyta: „Twoja babcia jest Polką i ratowała Żydów? Myślałem, że Polacy współpracowali z nazistami!”. Odpowiedź może być jedna: „Absolutnie nie!”.

Na tym jednak nie koniec. Rodzina Kowalskich przylatuje do Izraela. Marcin co prawda ciągle narzeka na „żydowską rodzinkę”, ale lody szybko topnieją, szczególnie że Jakub i jego syn Niki wciąż zapraszają na drinka, a w hotelu Polaków traktuje się jak bohaterów, co przejawia się również tym, że w hotelowym barku Marcin nie musi płacić za alkohol. Na dodatek Jan, już odpowiednio wyedukowany, zwierza się na Skypie Bognie i Barbarze, że odkrył tajemnicę rodzinną: jest Żydem, a jego matkę „wynieśli jacyś ludzie z białostockiego getta”. Na koniec, już w Warszawie, 
Barbara - która cały czas podkreśla, że nie jest bohaterką - oddaje swój medal tym, którym w jej przekonaniu bardziej się on należy: kładzie go na bezimiennym grobie rodziny Piątków, którzy oddali życie za ratowanie Żydów.

Jak zatem widać, Sprawiedliwi są dość siermiężną czytanką, pełną historycznych nieścisłości (konspiracja pomagająca Żydom w 1941 roku!) - i to czytanką o Polakach, nie o Żydach, o czym świadczy fakt, że z wyjątkiem postaci Iny Palomy oraz współczesnej części serialu żydowskie kwestie dialogowe są tu ograniczone do kilku zdań (i to wyłącznie w języku polskim). Zakłada się, że widz wie wszystko o akcji wysiedleńczej, obozach zagłady i powstaniu w getcie, więc nie warto o tym wspominać - slalomem ominięto również wszelkie drażliwe zagadnienia, od szmalcownictwa począwszy, na pytaniu o problemy powojenne skończywszy. Jednocześnie tego samego widza albo traktuje się jak idiotę, albo zakłada, że ma spaczony obraz kwestii ratowania Żydów. Odbiorcą idealnym jest tu ów Amerykanin spotkany na lotnisku, który posądza Polaków o kolaborację z Niemcami, choć jak wynika z historyjek pokazanych w Sprawiedliwych - Polacy mieli monopol na pomoc Żydom i nie było to dla nich bohaterstwo, ale coś zupełnie naturalnego. Warszawa Kowalskich staje się tutaj Warszawą pomagających - lub przynajmniej „życzliwie obojętnych”. Sprawiedliwi jednak długo czekali na sprawiedliwość (z przyczyn, których w serialu, oczywiście, się nie wyjaśnia), a teraz krzywdzi ich dodatkowo wraża zachodnia propaganda, powtarzająca kłamstwa o antysemityzmie, nie wspominając już o „polskich obozach koncentracyjnych”. Nawiasem mówiąc, Wojciech Tomczyk, zapytany w wywiadzie o udział innych narodów europejskich, w tym Holendrów, w ratowaniu Żydów, odpowiedział: „W Holandii sytuacja była zupełnie odmienna. Do końca wojny przetrwało w Amsterdamie otwarte getto, które było po prostu otwartą dzielnicą żydowską i w związku z tym nie możemy mówić o tym, że Żydzi holenderscy, a zwłaszcza Holendrzy pomagający Żydom byli w podobnej sytuacji co Polacy [...] Zresztą, w Holandii karą za pomoc Żydom nie była kara śmierci, tylko trzy miesiące obozu koncentracyjnego czy innej formy internowania - to bardziej przypomina kary mniej drakońskie niż kary ze stanu wojennego w Polsce”6. Słowa te należy chyba pozostawić bez komentarza.

Na koniec kilka słów o oglądalności. Produkcja cieszyła się sporą popularnością wśród widzów. Sprawiedliwi, pokazywani w Jedynce w niedziele po godz. 20.00, w rankingach oglądalności przegrali wyłącznie z Tańcem z gwiazdami - każdy odcinek oglądało średnio 2,73 mln widzów, zaś pierwszy, wyemitowany 11 kwietnia, w drugim dniu żałoby narodowej, aż 5,34 mln - co stanowiło jedną trzecią wszystkich osób oglądających wówczas telewizję? . W ten sposób, dzięki tragicznemu zbiegowi okoliczności i decyzjom osób układających telewizyjną ramówkę, Sprawiedliwi stali się nie tylko opowieścią o historii i bohaterskich czynach zwykłych ludzi, ale i sposobem na pokrzepienie serc narodu. Misja, przynajmniej teoretycznie, została wykonana.

\footnotetext{
${ }^{6}$ http://www.polskieradio.pl/trojka/TrojkaPoTrzeciej/artykul160879.html.
}

${ }^{7}$ Dane za Nielsen Audience Measurement, źródło: www.mediarun.pl. 